\title{
TINGKAT PENGUNGKAPAN CORPORATE SOCIAL RE- SPONSIBILITY BANK SYARIAH DI INDONESIA
}

\author{
Amalia Imroatul Azizah and M. Nur A. Birton \\ Universitas Muhammadiyah Jakarta \\ Emial: nur_birton@yahoo.com
}

\begin{abstract}
The implementation of corporate social responsibility has entered a new era is no exception in Islamic companies, especially of Islamic banking. Islamic Social Reporting Index is one way of measuring and reporting social responsibility for sharia entity. This study aimed to describe the practice of social responsibility disclosure based Islamic Social Reporting Index on Islamic banks in Indonesia is associated with the size of the Commercial Bank Based on Business Activities (BUKU). Using comparative descriptive method by means of content analysis on the elements of financial statements, this study using Islamic banks data annual report published in 2011-2013. The results showed an increase in items disclosure in each group BUKU. In general, Islamic banks ISR BUKU 2 disclosure scores higher than group Islamic banks BUKU 1. That is, the Islamic banks with equity of more than Rp 1 trillion to less than $\mathrm{Rp} 5$ trillion disclose social responsibility in a more specific and detailed than the equity less from Rp 1 trillion.
\end{abstract}

Keywords: social responsibility, Islamic banks, Islamic Social Reporting Index (ISR Index), BUKU (Commercial Bank based on Business Activities)

\section{PENDAHULUAN}

Di Indonesia praktik tanggung jawab sosial dan lingkungan (TJSL) perusahaan, umum disebut corporate social responsibility (CSR), memasuki tahapan baru. Bila pada awalnya masih bersifat wacana TJSL kini sudah menjadi regulasi dan karenanya bersifat wajib. Regulasi dimaksud antara lain termaktub dalam UU No. 22 tahun 2001 tentang Minyak dan Gas Bumi, khususnya pada pasal 11 (3); UU No. 25 Tahun 2007 tentang Penanaman Modal khususnya pasal 15 dan 16, sedangkan sanksi atas pengabaiannya tertuang dalam pasal 34 .

Regulasi yang bersifat umum namun menjadi tonggak TJSL, khususnya terhadap perseroan yang menjalankan usaha di bidang sumber daya alam, diatur dalam UU No. 40. Tahun 2007 Tentang Perseroan Terbatas. Selanjutnya, terbitnya Peraturan Pemerintah No. 47 Tahun 2012 tentang Tanggung Jawab Sosial dan Lingkungan Perseroan Terbatas melengkapi panduan penting bagaimana TJSL dilaksanakan. Ada dua isu penting dalam peraturan ini yang patut digarisbawahi. Pertama, TJSL menjadi tanggung jawab hukum seluruh perseroan (pasal 3); hal ini memperluas lingkup subjek hukum TJSL. Kedua, pengeluaran TJSL dapat menjadi biaya perseroan (pasal 5 ayat 2) dan pelaksanaannya dimuat dalam laporan tahunan perseroan serta 
dipertanggungjawabkan dalam rapat umum pemegang saham (pasal 6). Kedua pasal ini menjadi domain penting dalam perspektif akuntansi CSR.

Inilah titik balik praktik CSR yang sebelumnya hanya dilihat sebagai kepedulian perusahaan terhadap masyarakat dan lingkungannya (Khabibah dan Mutmainah, 2013). Apabila sebelumnya praktik CSR lebih menyasar korporasi di bidang ekstraktif, PP No 47 Tahun 2012 memberi legitimasi industri keuangan termasuk perbankan dalam aktivitas dan pengungkapan CSR, termasuk perbankan syariah (Fitriani dan Hartanti, 2010). Namun, entitas syariah secara intrinsik sudah terlibat dalam masalah sosial dengan adanya kewajiban zakat, infak/sedekah. Dalam hal pengungkapan, sejak tahun 2007, PSAK 101 Penyajian Laporan Keuangan telah pula mewajibkan penyajian Laporan Sumber dan Penggunaan Dana Zakat; dan Laporan Sumber dan Penggunaan Dana Kebajikan (IAI, 2014).

Terkait kebutuhan mengenai pengungkapan tanggung jawab sosial di perbankan syariah, Haniffa (2002) mengembangkan suatu indeks pelaporan yang disebut Islamic Social Reporting Index (indeks ISR). Kerangka ini dikembangkan khusus untuk pelaporan pertanggung jawaban sosial yang sesuai dengan prinsip Islam. Kerangka tersebut tidak hanya berguna bagi para pembuat keputusan, tetapi juga berguna membantu perusahaan Islami dalam memenuhi kewajiban terhadap Allah SWT dan masyarakat.

Di sisi lain, Bank Indonesia telah menerbitkan peraturan tentang modal inti dalam Peraturan Bank Indonesian Nomor 14/26/PBI/2012. Modal inti bagi bank yang berbadan hukum indonesia adalah modal inti sebagaimana dimaksud dalam ketentuan Bank Indonesia yang mengatur mengenai penyediaan modal minimum. Berdasarkan modal inti yang dimiliki bank dikelompokan menjadi 4 (empat) BUKU (Bank Umum berdasarkan Kegiatan Usaha). BUKU 1 dengan modal inti kurang dari Rp 1 triliun; BUKU 2 dengan modal inti paling sedikit Rp 1 triliun sampai Rp 5 triliun; BUKU 3 sebesar Rp 5 triliun sampai dengan kurang dari Rp 30 triliun; dan BUKU 4 paling sedikit Rp 30 triliun.

Penelitian ini melanjutkan kajian Setiani dan Birton (2014) yang hanya menekankan pada dua tema yaitu Finance and Investment dan Society. Temuan penting studi tersebut adalah bahwa ukuran bank syariah mengindikasikan tingkat pengungkapannya. Artinya, perusahaan lebih besar akan cenderung mengungkapkan informasi yang lebih spesifik dan detail. Selain menguji kembali tema (1) investasi dan keuangan, (2) masyarakat, maka ditambah lagi dengan tema (3) tata kelola perusahaan (corporate governance theme). Ketiga tema tersebut selanjutnya dikaitkan dengan BUKU sebagai ukuran resmi perbankan.

\section{KAJIAN PUSTAKA}

\subsection{CORPORATE SOCIAL RESPONSIBILITY}

The World Business Counsil For Sustainable Development (1999) dalam Kartini (2013) mendefinisikan CSR sebagai:

"The continuing commitment by business to behave etnically and con- 
tribute to economic development while improveing the quality of life of the workforce and their families as well as of the local communty and sosiety at large."

Jadi, CSR sebagai komitmen dunia usaha yang berkelanjutan untuk bertindak secara etis, beroperasi secara legal dan berkontribusi untuk peningkatan ekonomi, bersamaan dengan peningkatan kualitas hidup dari karyawan dan keluarganya sekaligus juga peningkatan kualitas komunitas lokal dan masyarakat luas.

Komponen CSR menurut Carroll (1979) dalam Kartini (2013) meliputi Economic Responsibilities, Legal Responsibilities, Ethical Responsibilities, dan Discretionary Responsibilities. Sasarannya, menurut The Jakarta Consulting Group, diarahkan baik ke dalam (internal) maupun ke luar (eksternal) perusahaan. Ke dalam, diarahkan kepada pemegang saham dalam bentuk profitabilitas serta karyawan dalam bentuk kompensasi-kompensasi yang adil. Ke luar, berkaitan dengan peran perusahaan sebagai pembayar pajak dan penyedia lapangan kerja, meningkatkan kesejahteraan dan kompetensi masyarakat, serta memelihara lingkungan tempat mereka beroperasi demi peningkatan kualitas hidup masyarakat dalam jangka panjang, baik untuk generasi saat ini maupun bagi generasi penerus.Selain itu tanggung jawab sosial perusahaan merupakan kepedulian perusahaan terhadap lingkungan sekitar. Hal ini sejalan dengan tiga prinsip dari Triple Bottom Line oleh Eklington (Khilda, 2010:30) yaitu People, Profit, and Planet. Perusahaan diharapkan tidak hanya mengejar keuntungan jangka pendek, tetapi perusahaan diharapkan berkonstribusi bagi peningkatan kesejahteraan dan kualitas hidup masyarakat dan lingkungan sekitar dalam waktu jangka panjang.

\subsection{TEORI CORPORATE SOCIAL RESPONSIBILITY}

Menurut Andreas (2011) terdapat lima teori yang dapat digunakan untuk memverifikasi pelaksanakan CSR secara tepat, sungguh-sungguh dan konsisten. Kelima teori tersebut adalah, pertama, teori stakeholder; kedua, teori legitimasi; ketiga, teori sustainabilitas korporasi; keempat, teori ekonomi politik; dan kelima, teori keadilan.

\subsection{PENGUNGKAPAN (DISCLOSURE)}

Pada umumnya di setiap perusahaan, pengungkapan atau pelaporan merupakan pemberian informasi atas konsekuensi atau bentuk pertanggung jawaban mengenai aktivitas yang telah dilakukan oleh perusahaan. Pengungkapan secara sederhana dapat diartikan sebagai penghargaan informasi (Sudarmadji dan Sularto, 2007). Sedangkan Noergraheni (2005) menyatakan bahwa bagi pihak di luar manajemen, laporan keuangan merupakan jendela informasi yang memungkinkan mereka melihat kondisi perusahaan tersebut. Informasi ini harus diungkapkan dalam laporan tahunan (annual report) atau dalam media lainnya, seperti web perusahaan. Luasnya informasi yang dapat diperoleh akan sangat tergantung pada tingkat pengungkapan dari laporan keuangan perusahaan yang bersangkutan. 


\subsection{ISR INDEX}

Kerangka ISR Index Haniffa (2002) secara lengkap berisi kompilasi item-item standar CSR yang ditetapkan AAOIFI (Accounting and Auditing Organization for Islamic Financial Institutions). Selanjutnya, Haniffa (2002) membaginya menjadi lima tema pengungkapan, (1) investasi dan keuangan (finance and investment), (2) produk dan jasa (product and Service), (3) tenaga kerja (employee), (4) masyarakat (society), dan (5) lingkungan (environment). Selanjutnya, Othman, et.al (2010) menambahkan satu lagi tema yaitu tata kelola perusahaan (corporate governance) sehingga menjadi enam.

Tema Investasi dan Keuangan, berisi mengenai informasi yang akan diungkapkan adalah apakah sumber keuangan dan investasi yang bebas dari bunga (riba) dan spekulasi bebas ( gharar) karena hal ini adalah sangat dilarang dalam Islam. Butiran-butiran yang termasuk dalam tema investasi dan keuangan misalnya seperti, (1) kegiatan yang mengandung riba, (2) mengandung ketidakjelasan (gharar), (3) Zakat, (4) kebijakan atas pembiayaan yang tertunda dan penghapusan piutang tak tertagih, (5) kegiatan investasi, dan (6) Proyek Pembiayaan. Tema kedua, produk dan jasa adalah tanggung jawab perusahaan untuk mengungkapkan semua produk atau jasa yang jatuh dalam kategori haram (dilarang).

Tema ketiga adalah karyawan, Islam ingin mengetahui apakah karyawankaryawan perusahaan telah diperlakukan secara adil dan wajar melalui informasiinformasi yang diungkapkan, seperti upah, karakteristik pekerjaan, jam kerja per hari, libur tahunan, jaminan kesehatan dan kesejahteraan, kebijakan terkait waktu dan tempat ibadah, pendidikan dan pelatihan, kesetaraan hak, keselamatan dan keamanan kerja, dan lingkungan kerja.

Tema keempat menekankan pentingnya saling berbagi dan meringankan beban orang lain dapat dilakukan dengan (1) sedekah, (2) wakaf, (3) qard hassan (meminjamkan sesuatu tanpa mengambil keuntungan), (4) Sukarela dari kalangan karyawan, (5) pemberian beasiswa sekolah, (6) pemberian kerja kepada lulusan sekolah/kuliah, (7) pengembangan generasi muda, (8) peningkatan kualitas hidup masyarakat, (9) kepedulian terhadap anak-anak, dan (10) menyokong kegiatan sosial kemasyarakatan/kesehatan.olahraga. Jumlah dan pihak yang menerima bantuan haruslah diungkapkan dalam laporan tahunan perusahaan. Seperti yang terncantum dalam Al-Qur'an: “ Jika kamu menangkap sedekah(mu), maka itu adalah baik sekali, dan jika kamu menyembunyikan dan kamu berikan kepada orang-orang fakir, maka menyembunyikannya itu lebih baik bagimu. Dan Allah akan menghapus sebagian kesalahan-kesalahanmu, dan Allah mengetahui apa yang kamu kerjakan (QS. Al-Baqarah: 271)" (Othman dan Thani, 2010).

Tema kelima yaitu lingkungan, menekankan pada konsep keseimbangan, kesederhanaan, dan tanggung jawab dalam menjaga lingkungan. Oleh karena itu, informasi-informasi yang berhubungan dengan penggunaan sumber daya dan program-program yang digunakan untuk melindungi lingkungan sekitar harus diungkapkan dalam laporan keuangan perusahaan. Dan tema keenam tata kelola perusahaan, perusahaan harus mengungkapkan semua kegiatan yang dilarang, seperti praktik monopoli, penimbunan barang, manipulasi harga, 
perjudian, dan segala jenis kegiatan yang melanggar hukum syariat Islam. Dalam tema tata kelola perusahaan ini butiran-butiran yang terkait dalam penilaian tanggung jawab sosial dalam ISR Indeks yaitu, (1) status kepatuhan terhadap syariah, (2) rincian nama direksi, (3) profil direksi/manajemen, (4) pernyataan mengenai renumerasi manajemen, (5) jumlah pelaksanaan rapat manajemen, (6) rincian tanggung jawab direksi/manajemen, (7) rincian nama dewan pengawas syariah, (8) profil dewan pengawas syariah, (9) rincian tanggung jawab dewan pengawas syariah, (10) pernyataan mengenai renumerasi dewan pengawas syariah, (11) jumlah pelaksanaan rapat dewan pengawas syariah, dan (12) struktur kepemilikan saham. Hal ini di tekankan dalam Firman Allah : "Dan janganlah kamu mencampur adukkan yang hak dengan yang bathil dan janganlah kamu menyembunyikan yang hak itu, sedang kamu mengetahui (QS. Al-Baqarah: 42)" (Othman dan Thani, 2010).

\section{METODE PENELITIAN}

Penelitian ini merupakan penelitian kualitatif deskriptif. Data yang digunakan dalam penelitian ini adalah data sekunder, baik internal maupun eksternal. Adapun objek penelitian ini adalah laporan tahunan 11 bank syariah, yang diperoleh melalui website masing-masing bank dan website Bank Indonesia yang berisi laporan tahunan publikasi bank dan Peraturan Bank Indoneisa No. 14/26/PBI/2012 tentang Modal Inti. Waktu penelitian dimulai pada bulan Februari 2015 sampai dengan Maret 2015.

Pada penelitian ini jumlah sampel yang digunakan adalah seluruh Bank Umum Syariah yang beroperasi di Indonesia yaitu dengan jumlah 11 bank. Berikut ini adalah nama-nama bank umum syariah yang menjadi sampel pada penelitian ini, yaitu : PT.Bank Muamalat Indonesia, PT. Bank Syariah Mandiri, PT. Bank Syariah Mega Indonesia, PT. Bank Rakyat Indonesia Syariah, PT. Bank Syariah Bukopin, PT. Bank Negara Indonesia Syariah, PT. Bank Victoria Syariah, PT. Bank Central Asia Syariah, PT. Bank Jabar Banten Syariah, PT. Panin Bank Syariah, dan PT. Bank MayBank Syariah.

Terdapat tiga tema pengungkapan ISR dalam penelitian, yaitu tema keuangan dan investasi, tema masyarakat, dan tema tata kelola perusahaan. Selain pengungkapan tanggung jawab sosial dengan menggunakan ISR. Dalam penelitian ini juga diungkapkan dengan menggunakan BUKU (bank umum berdasarkan kegiatan usaha). Kriteria pada buku yaitu tentang modal inti yang terdapat pada laporan keuangan tahunan bank syariah. Bank umum berdasarkan kegiatan usaha atau yang disebut dengan BUKU adalah pengelompokan bank berdasarkan kegiatan usaha yang sesuai dengan modal inti yang dimiliki. Pengelompokkan modal inti sesusai dengan kriteria BUKU 1 atau BUKU 2. BUKU 1 dengan modal inti yang dimiliki sampai dengan Rp 1 triliun, sedangankan BUKU 2 dengan modal inti yang dimiliki dari Rp 1 triliun sampai dengan $\mathrm{Rp} 5$ triliun. 
Penelitian ini menggunakan teknis analisis data deskriptif komparatif, dengan memberikan checklist pada tiap item yang mengungkapkan dua puluh delapan item yang terdapat pada ISR. Jika terdapat item yang diungkapkan maka akan mendapatkan skor "1"dan jika tidak diungkapkan maka akan mendapat skor " 0 ". Pemberian tanda checklist ini didasarkan pada analisis isi (content analysis) yang terdapat pada laporan tahunan. Teknis penulisan ini dilakukan dalam penelitian Fitria dan Hartanti (2010). Rumus yang digunakan untuk mengitung disclosure level setelah pemberian nilai pada indeks ISR selesai dilakukan.

$$
\text { Disclosurelevel }=\frac{\text { jumlahskordisclosure yang dipenuhi }}{\text { jumlahskormaksimum }}
$$

Setelah penghitungan disclosure level, dilakukan analisis deskriptif untuk menunjukkan besarnya nilai mean, standar deviasi, nilai minimum dan maksimum. Sedangkan teknis analisis data untuk modal inti yang terdapat dalam BUKU adalah dengan memasukan kriteria dalam BUKU 1 dan BUKU 2. Metode yang digunakan untuk menganalisis modal adalah mengelompokan bank yang termasuk dalam BUKU 1 sampai dengan BUKU 2.

\section{HASIL PENELITIAN DAN PEMBAHASAN}

\subsection{BANK UMUM SYARIAH (BUS) DI INDONESIA.}

Menurut data Bank Indonesia pada bulan Oktober 2013, kini sudah ada 11 Bank Umum Syariah (BUS), 23 Bank syariah dalam bentuk Unit Usaha Syariah (UUS), dan 160 Bank Perkreditan Rakyat Syariah (BPRS). Pada tahun 2011-2013 hanya empat bank umum syariah yang masuk dalam BUKU 2, selebihnya masuk BUKU 1 (lihat Tabel 1). Informasi mengenai total ekuitas 11 bank umum syariah dan pengelompokannya diperoleh dari website tiap-tiap bank dan Bank Indonesia.

Tabel 1 Pengelompokkan Bank Umum Syariah di Indonesia Menurut BUKU

\begin{tabular}{|c|l|c|c|c|c|c|c|c|}
\hline \multirow{2}{*}{ NO } & \multicolumn{2}{|c|}{ BANK } & \multicolumn{2}{c|}{$\begin{array}{c}\text { BUKU } \\
(\mathbf{2 0 1 1})\end{array}$} & \multicolumn{2}{c|}{$\begin{array}{c}\text { BUKU } \\
(\mathbf{2 0 1 2})\end{array}$} & \multicolumn{2}{c|}{$\begin{array}{c}\text { BUKU } \\
(\mathbf{2 0 1 3})\end{array}$} \\
\cline { 3 - 10 } & & $\mathbf{1}$ & $\mathbf{2}$ & $\mathbf{1}$ & $\mathbf{2}$ & $\mathbf{1}$ & $\mathbf{2}$ \\
\hline 1 & Bank Muamalat Indonesia (BMI) & & v & & v & & v \\
\hline 2 & Bank Syariah Mandiri (BSM) & & v & & v & & v \\
\hline 3 & Bank Syariah Mega Indonesia (BSMI) & v & & v & & v & \\
\hline 4 & Bank Rakyat Indonesia Syariah (BRIS) & v & & & v & & v \\
\hline 5 & Bank Syariah Bukopin (BSB) & v & & v & & v & \\
\hline 6 & Bank Negara Indonesia Syariah (BNIS) & & v & & v & & v \\
\hline 7 & Bank Victoria Syariah (BVS) & v & & v & & v & \\
\hline 8 & Bank Central Asia Syariah (BCAS) & v & & v & & v & \\
\hline 9 & Bank Jabar Banten Syariah (BJBS) & v & & v & & v & \\
\hline 10 & Panin Bank Syariah (PBS) & v & & v & & v & \\
\hline 11 & Bank MayBank Syariah (BMBS) & v & & v & & v & \\
\hline
\end{tabular}

Sumber: diolah 
4.2 PENGUNGKAPAN TANGGUNG JAWAB SOSIAL BERDASARKAN ISR DAN BUKU

\subsubsection{Pengungkapan Tanggung Jawab Sosial Berdasarkan Indeks ISR}

Berdasarkan 28 item pengungkapan ISR, perbankan syariah di Indonesia belum sepenuhnya mengungkapkan tanggung jawab sosialnya, sehingga Indeks ISR selama periode 2011-2013 sangat bervariasi. Meskipun demikian, bank syariah cenderung menunjukkan peningkatan ISR setiap tahunnya. Pengungkapan tertinggi pada tahun 2011 terdapat pada BSM yaitu sebanyak 26 item $(0,93)$; pengungkapan terendah pada BJBS sebanyak 8 item $(0,29)$. Di tahun 2012 pengungkapan tertinggi terdapat pada BMI dan BSM yaitu 26 item $(0,93)$ dan yang terendah terdapat BVS sebanyak 10 item $(0,36)$. Pada tahun 2013 BMI dan BSM masih bertahan dengan pengungkapan tertinggi yaitu 26 item $(0,93)$, dan terendah terdapat PBS dan BVS dengan perolehan 14 item $(0,5)$.

Berdasarkan tema, beberapa item pengungkapan pada tema investasi dan keuangan yang tidak diungkapkan bank syariah adalah item gharar dan kebijakan atas pembiayaan yang tertunda dan penghapusan pembiayaan tak tertagih. Walaupun demikian tema investasi dan keuangan ini dari 2011-2013 terus menunjukkan peningkatannya. Jika 2011 diperoleh skor rata-rata 0,52 , meningkat menjadi 0,56 (2012), dan terus meningkat pada 2013 hingga mencapai 0,58 .

Tema kedua yaitu Masyarakat juga meningkat. Jika tahun 2011 mendapatkan nilai rata-rata 0,41, meningkat menjadi 0,54 (2012), dan 0,58 (2013). Adapun bank dengan pengungkapan nihil yaitu BVS, BJBS, dan PBS (2011), pada tahun 2012.bank Victoria Syariah, dan terakhir Bank Victoria Syariah dan Panin Bank Syariah (2013).

Tema ketiga, tata kelola perusahaan. Tema ini paling banyak diungkapkan bank syariah dengan perolehan rata-rata yang kian meningkat pada setiap tahunnya. Tahun 2011 memperoleh rata-rata 0,87, 2012 memperoleh 0,88, dan 2013 meningkat menjadi 0,95.

1. Bank Muamalat Indonesia (BMI) pada tahun 2011 mengalami peningkatan dari 0,89 ke 0,93 (2012), dan mencapai nilai stabil kembali 0,93 di tahun 2013. Dengan begitu BMI dapat dikatakan baik dalam pengungkapan ISR karena memperoleh nilai yang lebih dari rata-rata 0,92 .

2. BSM merupakan bank yang paling tinggi dalam mengungkapkan Indeks ISR selama tiga periode (2011-2013). Selain itu BSM juga mempunyai skor 0,93 dan dinilai stabil, karena tidak mengalami penurunan maupun peningkatan. Nilai yang diperoleh bank BSM sudah melebih nilai rata-rata yaitu 0,93

3. Bank Rakyat Indonesia Syariah (BRIS) merupakan bank yang mengalami peningkatan setiap tahunnya, tahun 2011 BRIS memperoleh hasil scoring sebesar 0,61, tahun 2012 ternyata BRIS menunjukkan peningkatannya dengan perolehan skor 0,71 sampai dengan tahun 2013 skor yg dicapai 0,75 . Sudah melewati nilai rata-rata yang mencapai 0,69 .

4. Bank Negara Indonesia Syariah (BNIS) merupakan bank dengan perolehan hasil Indeks ISR tahun 2011 sebesar 0,79 yang mengalami kestabilan ditahun 
2012 dengan nilai 0,79. Peningkatan terjadi pada tahun 2013 mencapai 0,86. Dengan rata-rata yang dimiliki adalah 0,81 .

5. Bank Syariah Mega Indonesia (BSMI) mengalami penurunan dan peningkatan yang terjadi pada tahun 2011 dengan perolehan disclosure level 0,64. Kemudian pada tahun 2012 menurun menjadi 0,57. Peningkatan terjadi tahun 2013 dengan perolehan nilai 0, 68 .

6. Bank Syariah Bukopin (BSB) mengalami peningkatan. Tahun 2011 perolehan nilai sebesar 0,61 meningkat menjadi 0,79 (2012), dan 0,82 (2013).

7. BJBS menjadi bank dengan pengungkapan terkecil yaitu 0,29 (2011). Tahun 2012 meningkat menjadi 0,61, meningkatlagi menjadi 0,79 (2013).

8. PBS masih tergolong rendah untuk mengungkapkan kegiatan CSR akan tetapi terus mengalami peningkatan. Pada tahun 2011 jumlah total yang dimiliki PBS sebesar 0,39, tahun 2012 meningkat menjadi 0,54, akan tetapi pada tahun 2013 mengalami penurun menjadi 0,5.

9. Bank Central Asia Syariah (BCAS) memperoleh skor 0,68 (2011), menjadi 0,71 (2012) dan 0,75 (2013).

10. BVS selama tiga periode 2011-2013 mengalami penurunan 0,46 (2011) dan menurun menjadi 0,36 (2012), meningkat kembali di tahun 2013 menjadi 0,5.

11. BMBS selama periode 2011-2013 cukup stabil dengan nilai 0,64.

\subsubsection{Pengungkapan Tanggung Jawab Sosial Berdasarkan BUKU}

Terdapat 4 bank syariah yang termasuk dalam kategori BUKU 2, dan 7 bank syariah yang termasuk dalam kotegori BUKU 1. Pembahasan ini menekankan pada hubungan antara BUKU dengan tingkat pengungkapan tanggung jawab sosial di bank syariah.

Tabel 2 Pengungkapan Tanggung Jawab Sosial Menurut BUKU Tahun 2011

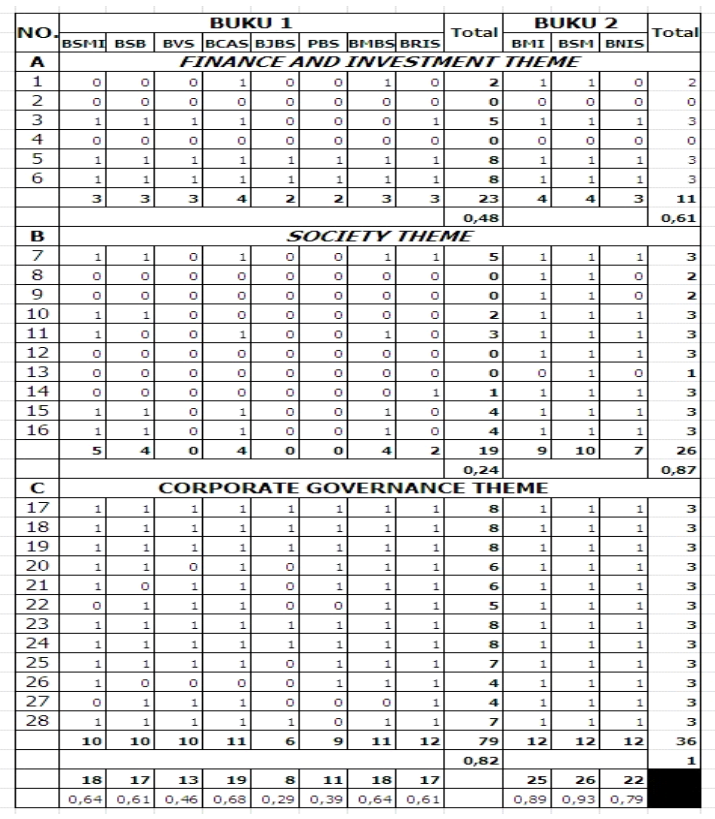


Sumber:Data diolah

Berdasarkan tabel di atas dapat diketahui bahwa tahun 2011 pada BUKU 1 terdapat delapan bank syariah dan BUKU 2 terdapat tiga bank syariah. Pada Finance and Investment Theme terlihat bahwa jumlah tema ini lebih tinggi pada BUKU 2 yaitu 0,61, pada tema ini item gharar dan item kebijakan atas pembiayaan yang tertunda tidak diungkapkan oleh seluruh bank. Sedangkan pada BUKU 1 diperoleh hasil 0,48. Pada Society Theme pada BUKU 2 memiliki rata-rata 0,87 lebih tinggi dibandingkan rata-rata yang terdapat pada BUKU 1 yaitu 0,24. Corporate Governance Theme. BUKU 1 masih terlihat rendah yaitu 0,82 . Pada BUKU 2 rata-rata yang dimiliki lebih tinggi dari BUKU 1 yaitu 1. Karena seluruh bank yang terdapat pada BUKU 2 mengungkapkan seluruh item yang ada pada Corporate Governance Theme.

Dari 28 item yang diungkapkan pada tahun 2011, item kegiatan investasi, proyek pembiayaan, status kepatuhan terhadap syariah, rincian nama direksi, profil direksi, rincian nama DPS, dan profil DPS. Seluruhnya diungkapkan oleh kesebelas bank syariah, yaitu BMI, BSM, BRIS, BNIS, BSMI, BSB, BCAS, BJBS, BVS, PBS, dan BMBS.

Item kegiatan yang mengandung riba hanya diungkapkan oleh empat bank, yaitu BCAS, BMBS, BMI, dan BSM. Item zakat di tahun 2011 terdapat delapan bank yang mengungkapkannya. Adapun kedelapan bank tersebut adalah, BMI, BSM, BNIS, BRIS, BCAS, BVS, BSB, dan BSMI. Item pemberian donasi terdapat delapan bank yang mengungkapkan, BMI, BSM, BNIS, BRIS, BMBS, BCAS, BSB, dan BSMI.

Tabel 3 Pengungkapan Tanggung Jawab Sosial Menurut BUKU Tahun 2012

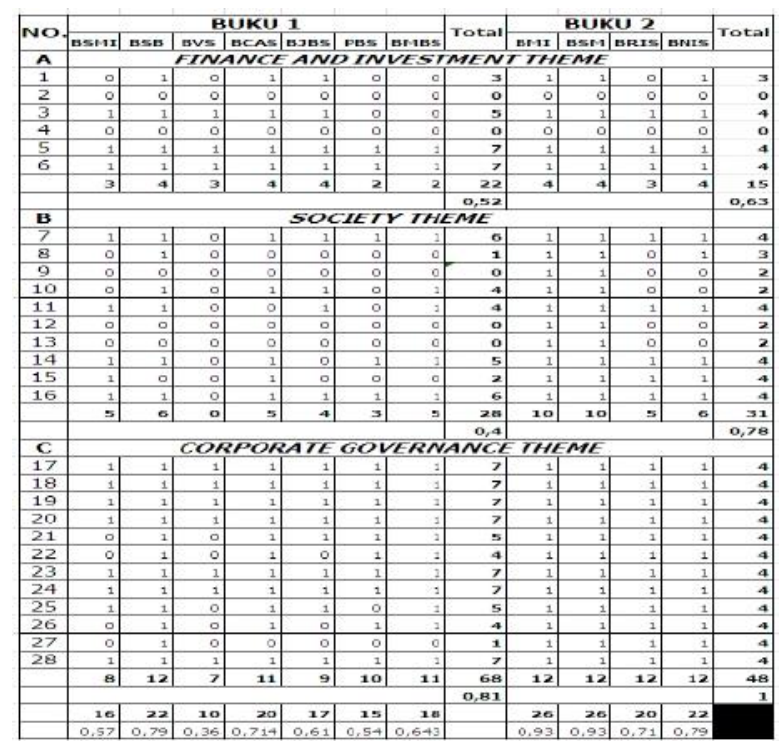

Sumber : Data diolah 
Pada Tabel 3 terlihat bahwa ada peningkatan jumlah bank syariah yang terdapat pada BUKU 2, yaitu BRIS. Karena modal inti yang dimiliki oleh BRIS di tahun 2012 sudah masuk dalam kategori BUKU 2. Untuk itu tahun 2012 jumlah bank syariah pada BUKU 2 menjadi empat bank syariah dan pada BUKU 1 menjadi tujuh bank syariah. Finance and Investment Theme di tahun 2012 mengalami peningkatan pada BUKU 1 dan BUKU 2. Akan tetapi, tetap saja BUKU 2 memperoleh rata-rata 0,63, lebih tinggi dibandingkan BUKU 1 yang memperoleh 0,52. Pada Society Theme BUKU 1 memiliki rata-rata 0,4 lebih rendah dibandingkan dengan rata-rata yang diperoleh oleh BUKU 2 yaitu 0,78. Ratarata yang diperoleh dari tema terakhir Corporate Governance Theme BUKU 1 dengan rata-rata 0,81 lebih rendah dibandingkan rata-rata yang diperoleh BUKU 2 yaitu 1.

Dari 28 item yang terdapat pada pengungkapan ISR tahun 2012. Terdapat item-item yang diungkapkan oleh kesebelas bank syariah, yaitu item kegiatan investasi, proyeksi pembiayaan, status kepatuhan terhadap syariah, rincian nama direksi, profil direksi, rincian tanggung jawab direksi, rincian nama DPS, profil DPS, dan struktur kepemilikan saham.

Pengungkapan item yang mengandung riba meningkat menjadi 6 bank dengan sebelumnya hanya empat bank (2011), yaitu BSB, BCAS, BJBS, BMI, BSM dan BNIS. Tahun 2012 pengungkapan item zakat juga mengalami peningkatan menjadi sembilan bank, yaitu BMI, BSM, BRIS, BNIS, BSMI, BSB, BVS, BCAS, dan BJBS. Item selanjutnya yang berkaitan dengan kegiatan sosial yaitu pemberian donasi (shodaqah) dan item menyokong kegiatan sosial yang mengalami peningkatan jumlah bank yang mengungkapkan item ini. Ada sepuluh bank yang mengungkapkan item ini BSMI, BSB, BCAS, BJBS, PBS, BMBS, BMI,BSM, BRIS, dan BNIS.

Berdasarkan tabel 4 dibawah, pada Finance and Investment Theme BUKU 1 memperoleh rata-rata sebesar 0,55 sedangkan BUKU 2 memperoleh rata-rata sebesar 0,63. Pada Society Theme BUKU 1 memperoleh rata-rata sebesar 0,43 dan BUKU 2 memperoleh rata-rata sebesar 0,85 . Pada Corporate Governance Theme, BUKU 2 memperoleh rata-rata 1 dan BUKU 1 memperoleh rata-rata sebesar 0,93 , yang artinya BUKU 2 mendapatkan rata-rata tertinggi dari BUKU 1 .

Dari 28 item yang terdapat pada pengungkapan ISR Indeks tahun 2013. Item kegiatan investasi, proyeksi pembiayaan, status kepatuhan terhadap syariah, rincian nama direksi, profil direksi, rincian tanggung jawab direksi, rincian nama DPS, profil DPS dan rincian tanggung jawab DPS. Keseluruh item tersebut diungkapkan oleh kesebelas bank syariah.

Tahun 2013 pengungkapan item mengandung riba mengalami peningkatan 1 entitas menjadi 7. Ketujuh bank yang mengungkapkan adalah BMI, BSM, BNIS, BMBS, BJBS, BCAS, dan BSB. Sedangkan item zakat memperoleh nilai yang statis, hanya diungkapkan 9 bank, yaitu BMI, BSM, BRIS, BNIS, BSMI, BSB, BVS, BCAS, dan BJBS. Pada item pemberian donasi (shodaqah), tahun 2013 mengalami penurunan menjadi 9 dari 10 tahun 2012. 
PBS menyumbang penurunan ini, selain itu PBS juga tidak lagi mengungkapkan item menyokong kegiatan sosial.

Hasil penelitian ini berbeda dengan temuan Ahzar dan Trisnawati (2013) yang menyatakan bahwa bank syariah lebih fokus pada kegiatan sosial, sekalipun dengan presentase $10,3 \%$. Sebab, pada tahun 2011 ada bank syariah yang sama sekali tidak mengungkapkan tema sosialnya, yaitu Bank Victoria Syariah.

Hasil ini mengonfirmasi temuan Fitria dan Hartanti (2010) bahwa bank syariah di Indonesia sudah baik dalam mengungkapkan ISR Indeks walaupun belum sempurna. Hasil ini juga sejalan dengan penelitian Setiani dan Birton (2014) yang melihat bank syariah besar cenderung mengungkapkan informasi yang lebih spesifik dalam laporannya. Perbedaannya, penelitian Setiani dan Birton (2014), tidak menjelaskan secara rinci ukuran besar kecilnya bank syariah sebagaimana temuan ini.

Tabel 4 Pengungkapan Tanggung Jawab Sosial Menurut BUKU Tahun 2013

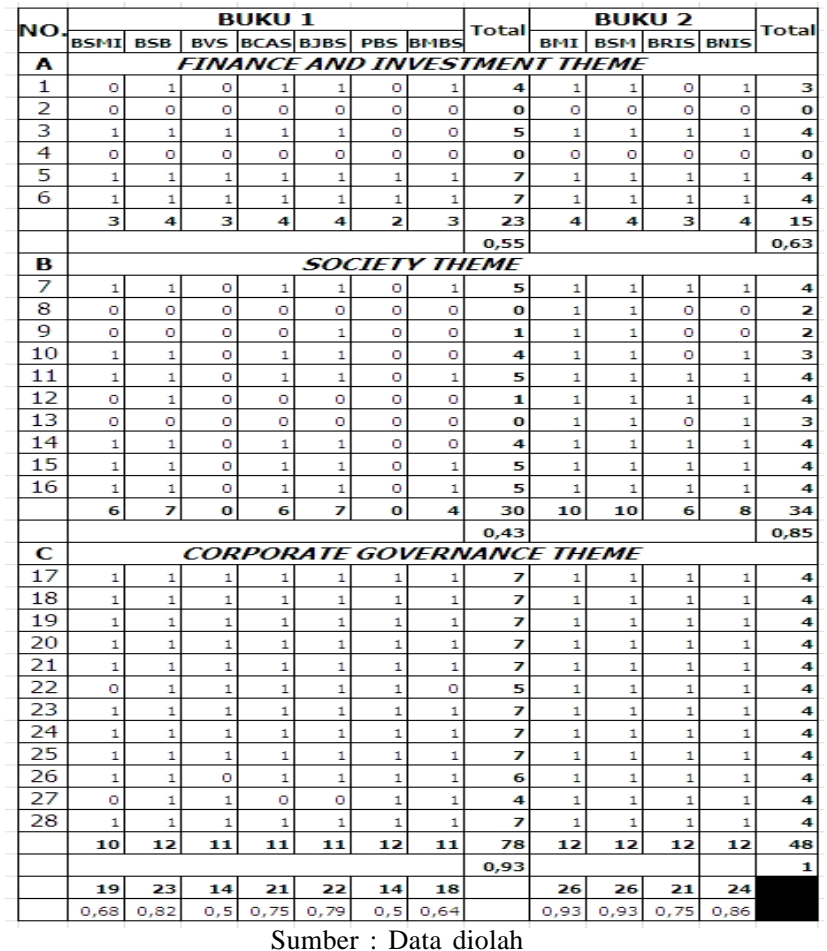

\section{SIMPULAN DAN SARAN}

SIMPULAN

Hasil penelitian ini memperlihatkan, pengungkapan ISR Indeks bank umum syariah di Indonesia selama periode 2011-2013 mengalami perbaikan terusmenerus. Kisaran total skor dari angka terendah ke yang tertinggi yaitu sebesar 
0,29 - 0,93 (2011) meningkat menjadi 0,36 - 0,93 (2012) dan meningkat lagi menjadi 0,5 - 0,93 (2013). Bank kategori BUKU 2 selalu memiliki nilai tertinggi dibandingkan BUKU 1. Pada BUKU 2, BSM secara konsisten mencapai skor tertinggi 0,93, disusul BMI. Sedangkan pada BUKU 1, terdapat variasi nilai terendah. BJBS mendapatkan skor terendah 0,29 (2011), BVS dengan skor 0,36 (2012), sedangkan tahun 2013 PBS dan BVS sama-sama memperoleh skor 0,5. Angka indeks ISR tampaknya berbanding lurus dengan besarnya BUKU. Hubungan lain yang dapat ditarik adalah makin lama suatu bank beroperasi dan memiliki modal besar cenderung mengungkapkan tanggung jawab sosialnya secara spesifik dan rinci. Sebaliknya, bank yang baru beroperasi dan memiliki modal kecil tidak mengungkapkan tanggung jawab sosialnya secara spesifik.

\subsection{SARAN}

Pertama, bank umum syariah yang termasuk dalam kategori BUKU 1, perlu memperbaiki pengungkapan ISR-nya, sedangkan Bank Umum Syariah BUKU 2 perlu dapat mempertahankan skor yang diperolehnya. Kedua, peneliti selanjutnya diharapkan (1) menambahkan butir dan jumlah tema ISR; (2) melihat periode operasi dengan indeks ISR, dengan demikian (3) dapat menggunakan metode yang berbeda untuk melihat hubungan yang kompleks tersebut.

\section{DAFTAR PUSTAKA}

\section{Al-Qur'anul Karim}

Ahzar, Fahri Ali dan Rina Trisnawati. 2013. Pengungkapan Islamic Social Reporting pada Bank Syariah di Indonesia. Proceeding Seminar Nasional dan Call For Papers Sancall 2013. Surakarta 23 Maret 2013. Universitas Muhammadiyah Surakarta.

Fitria, Soraya dan Dwi Hartanti. 2010. Islam dan Tanggung Jawab Sosial: Studi Perbandingan Pengungkapan Berdasarkan Global Reporting Initiative Indeks dan Islamic Social Reporting Indeks. Simposium Nasional XIII. Purwokerto.

Haniffa, Ros. 2002. Social Reporting Disclosure: An--Islamic Perspective. Indonesian Management \& Accounting Research, Vol. 1 No. 2, pp. 128146.

Ikatan Akuntan Indonesia. 2014. Penyajian Laporan Keuangan Entitas Syariah. Salemba Empat. Jakarta.

Ikhsan. Arfan 2008. Methode Penelitian Akuntansi Keprilakuan. Graha Ilmu. Yogyakarta.

Juanda. 2009. Metode Analisis Data. Media Presindo. Yogyakarta. 
Kartini, Dwi. 2013. Corporate Social Responsibility Transformasi Konsep Sustainability Managemen dan Implementasi di Indonesia. Refika Adisama. Bandung.

Khabibah, Anny Nibras dan Siti Mutmainah. 2013. Analisis Hubungan Corporate Social Responsibility (CSR) dan Coporate Financial Performance pada Perbankan Syariah di Indonesia. Diponegoro Journal of Accounting Volume 2. Nomer 3. Tahun 2013. Halaman: 1-11.

Kholishoh, Khilda. Skripsi. 2010. Pendayagunaan Dana CSR. PT. BNI (Pesero) TBK Melalui Program Mitra Binaan. Universitas Islam Negeri Jakarta. Jakarta.

Lako, Andreas. 2011. Dekonstruksi CSR \& Reformasi Paradigma Bisnis dan Akuntansi. Erlangga Jakarta.

Nazir, Moh. 2014. Metode Penelitian. Ghalia Indonesia. Bogor.

Noegraheni L. 2005. Pengaruh Karakteristik Perusahaan Terhadap Kualitas Pengungkapan Sukarela Dalam Laporan Tahunan pada Perusahaan Publik Non Industri Keuangan di Bursa Efek Jakarta. Jurnal Equity, Vol. 2. No. 1.

Othman, Rohana, Azlan MD Thani, E.K Ghani. 2009. Determinants of Islamic Social Reporting Among Top Shariah-Approved Companies In Bursa Malaysia. Research Journal of Internasional Studies Vol 12.

Othman, Rohana dan Azlan MD Thani. 2010. Islamic Social Reporting Of Listed Componies In Malaysia. International Business \& Economics Research Journal. Vol. 9. No. 4. Malaysia.

Peraturan Bank Indonesia No. 14/26/PBI/2012. Tentang Jaringan Kantor dan Modal Inti Pada Perbankan.

Peraturan Pemerintah No. 47 Tahun 2012 Tentang Tanggung Jawab Sosial dan Lingkungan.

Sekaran, Uma. 2006. Research Methode For Business. Salemba Empat. Jakarta.

Setiani, Andita dan M. Nur A. Birton. 2014. Praktik Pengungkapan Berbasis Islamic Social Reporting pada Bank Syariah di Indonesia. Simposium Nasional Akuntansi Syariah, UIN Syarief Hidayatullah Jakarta.

Sudarmadji, Ardi Murdoko dan Lana Sularto, 2007. Pengaruh Ukuran Perusahaan, profitabilitas, Leverage, dan Tipe Kepemilikan Perusahaan Terhadap Luas Voluntary Disclosure Laporan Keuangan Tahunan. Proceeding PESAT. 
Vol. 2

Sugiyono. 2014. Metode Penelitian Kuantitatif, Kualitatif, Dan R\&D. Alfabeta. Bandung.

Undang-Undang No. 22 Tahun 2001 Tentang Minyak Dan Gas Bumi.

Undang-Undang No. 25 Tahun 2007 Tentang Penanaman Modal.

Undang-Undang No. 40 Tahun 2007 Tentang Perseroan Terbatas.

http://www.syariahbukopin.co.id

http://www.bcasyariah.co.id

http://www.syariahmandiri.co.id

http://www.bankvictoriasyariah.co.id

http://www.bjbsyariah.co.id

http://www.bnisyariah.co.id

http://www.paninbanksyariah.co.id

http://www.brisyariah.co.id

http://www.megasyariah.co.id

http://www.maybanksyariah.co.id

http://www.muamalatbank.co.id 